Relations industrielles

Industrial Relations

\title{
Social Security in Great Britain
}

\section{Edgar Guay}

Volume 5, numéro 4, janvier 1950

URI : https://id.erudit.org/iderudit/1023317ar

DOI : https://doi.org/10.7202/1023317ar

Aller au sommaire du numéro

\section{Éditeur(s)}

Département des relations industrielles de l’Université Laval

\section{ISSN}

0034-379X (imprimé)

1703-8138 (numérique)

Découvrir la revue

Citer cet article

Guay, E. (1950). Social Security in Great Britain. Relations industrielles /

Industrial Relations, 5(4), 31-32. https://doi.org/10.7202/1023317ar

Tous droits réservés @ Département des relations industrielles de l’Université Laval, 1950
Ce document est protégé par la loi sur le droit d'auteur. L'utilisation des services d'Érudit (y compris la reproduction) est assujettie à sa politique d'utilisation que vous pouvez consulter en ligne.

https://apropos.erudit.org/fr/usagers/politique-dutilisation/ 


\section{Industrial Relations Bulletin}

Volume 5, number 4

QUEBEC

January 1950

\section{SOCIAL SECURITY IN GREAT BRITAIN}

Edgar Guay

The Bristisher, man of action, has expressed his concept of «social security 》 in a vast network of social services synchronized with a national insurance system covering all the common risks «from womb to tomb», as the usual expression has it.

Although the plan at the base of the legislation instituting the services and integrating them in a rational fashion was the work of an interdepartmental committee, the personal attainments of its chairman, Lord Beveridge, were so great that his name has been used to designate the document since its publication in 1942. The plan is the result of the pressure of two problems - one in the administrative, the other in the social field.

In 1942, the administrative network for the public social services was likened to a jungle where the citizen had difficulty in finding his bearings in spite of the aid of Citizen's Advice Bureaus and the information services of the Trade Unions. Seven ministries, about two hundred local authorities, hundreds of Mutual Aid Societies and insurance companies interwove their activity in this field.

The classic social problem, poverty, had been put on their agenda by a series of scientific surveys conducted in the great industrial centres. As well as exposing the extent of the evil and its causes, these enquiries revealed the sufficiency of the community's resources for putting an end to it. A simple redistribution of income would cause the disappearance of the insufficient financial resources of the economically feeble. This redistribution of income would be operated by a system of social insurance and connected free services to which all could have recourse by right and without a «means test».
A policy of full employment would also have to be elaborated. Employment, actually, by assuring revenue is the corner stone of social security. Beveridge recognized the limitations of such a system by affirming that it was a minimum on which citizens could build freely.

The recommendations of the Beveridge Report have been implemented by a series of legal measures and the putting into effect of four classes of interdependant services: 1. The Income Services, 2. Employment and Rehabilitation, 3. Health Services, 4. Welfare Services of Local Authorities.

The first class is composed of the social insurances to which all citizens contribute according to their status, as also employers and the State. Familly allowances, which help to maintain at a reasonable level the income of growing families, are part of this department. Also National Assistance, which insures continuity of income in cases of urgency or of cessation of the right to the social insurances.

The population as a whole is protected by more than a thousand local social insurance offices and three hundred National Assistance offices, and by uncounted committees where all classes of the community are represented. This Ministry of National Insurance watches over the good administration of this section.

A similar network of employment offices facilitates the passage from one job to another. These offices maintain close relations with industrial rehabilitation centres so that all citizens may have the advantage of finding remunerative employment. This group of services is confided to the Ministry of Labour.

The Ministry of Health, for its part, directs the medical services to which all citizens have 
free access without regard to their status with the National Insurance. Hospitals, clinics, specialists, doctors, dentists, pharmaceutical products, opthalmic services, all are put at the disposition of the humblest citizen and even of the foreign visitor. In practice, this section is entirely financed by the Exchequer by means of taxation.

The city and county municipalities also put welfare institutions at the disposition of the needy population: Old peoples' Homes supported by the State, Child Welfare Centres, Family Aid Services and other connected services destined to complete on the local level the great national services.

The burden of the total cost of all these services can be realized when we remember that before the War the Government collected about $20 \%$ of the national revenue while to-day it receives $37 \%$. Before the War about $8 \%$ of government expenses occurred in the social services section; at the present time this percentage has risen to $16 \%$ which corresponds to an increase of nearly $100 \%$.

This policy of redistributing income has had for effect the levelling of individual wealth. In 1939 more than 11,000 persons in England enjoyed an annual income of more than 5000 pounds sterling after the usual deductions: today the number of these favoured of fortune has fallen to about 250. The system of redistribution has been so efficient that Sir Stafford Cripps, in the Budget Speech of last April, let it be clearly understood that no more redistribution of income could be engaged in without crippling the national economy.

The cost of administration is also covered by the three-way contributions. For the insurance, for example, the employee pays four shillings and tuppence weekly, his employer four shillings and eleven pence which makes a total of nine shillings and a penny ( $\$ 1.82$ before the recent devaluation). The government furnishes another total amount equivalent to $42 \%$ of the total cost of the social insurances. The other social security services are also financed from taxation.

This plan, which includes the whole population, has undergone for about fifteen months the test of being put into practice. General results have been obtained, e.g. $95 \%$ of the British people have consulted the health services and the administrative cost of this section exceeded the esti- mates by $100 \%$ in spite of the voluntary participation of 10,000 citizens in the administrative committees. In January, 1949, the National Assistance counted on its lists more than a million clients of whom three-quarters received social insurance benefits. Beveridge had forecast for this organization a back-ground role but it seems to have taken on importance because of the relative inability of the National Insurance to give to the British the anticipated subsistance minima.

None of the great English political parties oppose these measures of social security. The Liberal Party pride themselves with having initiated the movement with the legislation of Lloyd George in 1911 and with having stepped in in 1942 with their illustrious representative, Lord Beveridge. It favours a political administration following a line which deviates neither to the left nor to the right. But this party, in spite of efforts to relaunch it, has practically no influence.

The Conservative Party also claims to have fathered the larger part of the social legislation. Churchill and Sir John Anderson have worked at erecting a structure of public social services since the beginning of their political careers. The Beveridge Report was produced at the demand of the Coalition Government directed by Churchill. The Conservative Party, at the present time, desires to maintain all the social services but hopes for a better administration by drawing the attention of the electorate to the high costs. It asks this question of the people, « How can England support these services?》

To this question the Labourites, with Aneurin Bevan, answer, "As long as there is need ». It may be asked what will be, in practice, the conduct of the party in power since Sir Stafford Cripps, in the last budget estimates recommends, as a measure of economy, stopping the construction of health centres everywhere in the country. More, a contribution of 0.14 will be required of the patient for each medical prescription he brings to the pharmacy. They hope thus to diminish somewhat the terrific number of $187,000,000$ prescriptions given out gratuitously in 1948-1949.

The data of the vital statistics for the fiscal year 1948-1949 and the economic repercussions of recent devaluation will probably be factors influencing the immediate future of social security in Great Britain. 